\title{
"Credit provision by banks: a case study analysis of small businesses in South Africa"
}

\begin{tabular}{ll} 
AUTHORS & Raphael N. Ngcobo \\
\hline ARTICLE INFO & $\begin{array}{l}\text { Raphael N. Ngcobo (2017). Credit provision by banks: a case study analysis of } \\
\text { small businesses in South Africa. Banks and Bank Systems, 12(4), 65-74. } \\
\text { doi:10.21511/bbs.12(4).2017.06 }\end{array}$ \\
\hline DOI & http://dx.doi.org/10.21511/bbs.12(4).2017.06 \\
\hline RELEASED ON & Thursday, 30 November 2017 \\
\hline RECEIVED ON & Thursday, 10 August 2017 \\
\hline ACCEPTED ON & Monday, 18 September 2017 \\
\hline LICENSE & $\begin{array}{l}(\text { (c) }) \text { Er-Ne } \\
\text { This work is licensed under a Creative Commons Attribution-NonCommercial } 4.0\end{array}$ \\
\hline JOURNAL & International License \\
\hline ISSN PRINT & "Banks and Bank Systems" \\
\hline ISSN ONLINE & $1816-7403$ \\
\hline PUBLISHER & $1991-7074$ \\
\hline FOUNDER & LLC “Consulting Publishing Company "Business Perspectives" \\
\hline
\end{tabular}

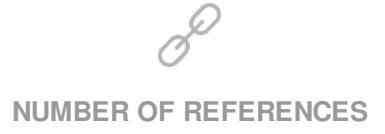

31

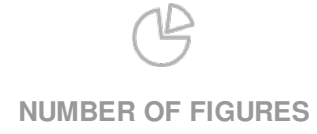

0
NUMBER OF TABLES

7

(C) The author(s) 2022. This publication is an open access article. 


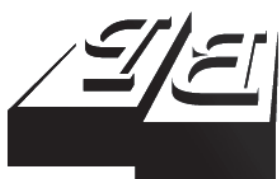

BUSINESS PERSPECTIVES

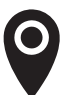

LLC "CPC "Business Perspectives" Hryhorii Skovoroda lane, 10, Sumy, 40022, Ukraine

www.businessperspectives.org

Received on: $10^{\text {th }}$ of August, 2017 Accepted on: $18^{\text {th }}$ of September, 2017

(c) Raphael N. Ngcobo, 2017

Raphael N. Ngcobo, Senior Lecturer, Department of Financial Accounting, UNISA, South Africa.

\title{
CREDIT PROVISION BY BANKS:
} A CASE STUDY ANALYSIS OF SMALL BUSINESSES IN SOUTH AFRICA

\begin{abstract}
Small business sector is considered as an important economic driver by many countries. In South Africa, small business sector has been acknowledged as the driving force to boost the economic growth and an important source of job creation. This article aims at identifying factors that are a challenge in obtaining bank finance by small businesses in South Africa.

Primary data for this study involved a survey questionnaire directed to owners of small businesses operating in Ekurhuleni Metropolitan area, Gauteng, South Africa. Factors that were deemed to influence bank loan decision were examined. The research findings revealed that factors such as age of business, business plans availability, educational background of business owner, experience of business owner and availability of a collateral have an influence on the bank loan decisions. This research also found that the accessibility of loan funding from banks was a constraint on business operations and growth. The findings of this study indicate that the mentioned factors are a challenge for small businesses in accessing bank loans to fund their operations.
\end{abstract}

The findings of this study will be of great value to small business owners and policy makers in finding solutions to address the identified barriers.

Keywords small business, bank loans, financing, barriers

JEL Classification G21

\section{INTRODUCTION}

A vibrant and growing small business sector is a significant characteristic of a flourishing and growing economy. The small business sector in South Africa plays an important role in economic growth, employment creation, income generation and reducing levels of inequality. Despite the importance of the small business sector's role in the South African economy, the country is ranked well behind fellow African countries in its ability to establish, sustain and grow successful new businesses. The latest Global Entrepreneurship Monitor (GEM) report indicates that entrepreneurship in South Africa has declined during 2015 and 2016 (Harrington \& Kew, 2016). The 2016 GEM report revealed that the entrepreneurial intentions in South Africa have dropped by almost $30 \%$ (from $15.4 \%$ to $10.9 \%$ ) when compared to 2013 and almost halved when compared to 2010 (GEM, 2016). The report further paints a disappointing picture about the country's entrepreneurial intentions which is reported to be 3.6 times lower than the African average (GEM, 2016). In South Africa, a disappointingly high number of Small, Medium-sized Entities (SMEs) fail during the first few years of operation (Nieman \& Nieuwenhuizen, 2009).

The financing of small businesses is an area that has attracted much attention within the business fraternity and has become an important 
topic for policymakers and researchers in this country. This interest has mainly been driven in part by the fact that the financing of small businesses has been cited as one of the sources that can be attributed to the failure of these business entities. The government has devised many policy interventions and announced various incentives to help this sector yet financing continues to be one of the key developmental constraints for this sector.

It is widely noted that an important aspect for an upcoming business is the access to finance mainly from financial institutions. Business entities require external finance to realize their full potential, if not at their establishment then at some stage in their growth. Berger and Udel $(1998,2002)$ found that most of the external financing such as, short- to medium-term loans, are provided by banks. Therefore, the advancement, sustainability and ultimately progression of small business enterprises are largely dependent on the financial support and funding by banks.

Many studies have found that small businesses both in developed and developing countries face major constraints in obtaining bank loans (Bosa, 1969; Levy, 1993; Keasey \& Watson, 1994). There is also evidence of small to medium size entities, within formal sector also facing challenges in obtaining some form of finance which has been identified as a limiting factor of economic growth to many countries (Beck \& Kunt, 2006). The purpose on which this study was based, was to identify the factors that are a barrier around small businesses to access finance from banks in South Africa.

\section{THE SOUTH AFRICAN SMALL BUSINESS SECTOR}

The South Africa's Depatment of Trade and Industry classifies a small business as micro, very small, small or medium enterprises (SMMEs), following a complex set of thresholds per industry, as scheduled in the National Small Business Act. SMMEs are not restricted to formally registered enterprises (such as close corporations, private companies and co-operative enterprises) but include informal and non-VAT registered enterprises, such as survivalist street trading enterprises, backyard manufacturing and services, and occasional home-based evening jobs (The DTI, 2008).

A large majority of small businesses in South Africa are concentrated on the very lowest end, where survivalist businesses are found (Berry, 2002). These businesses can take the form of street trading enterprises, backyard manufacturing and services, and occasional home-based evening jobs (The DTI, 2008). It is estimated that small businesses in South Africa constitute 91\% of formalized businesses, provide employment to about $60 \%$ of the labor force and total economic output accounts for roughly $34 \%$ of the Gross Domestic Product (GDP) (The Association of Banking South Africa, 2016). The important role of small business sector in this country positions it as the engine through which the growth objectives of this country can be achieved.

Whilst South Africa enjoys advanced infrastructure than most of the African economies, the country's economic growth has been modest at best. The second largest economy in Africa has witnessed economic growth at an average of $4.5 \%$ between 2002 and 2008 (Stats S A, 2016). That has been its largest growth since the new political order in 1994. Statistics indicate that in the past five years, the country has recorded an average of $2.6 \%$ in economic growth rate (Stats S A, 2016). These figures indicate that the country's main social problems take a center stage and consequently unemployment is a big challenge.

Small and informal business sector has an important role in the modern-day economy (Chimucheka, 2015). The role of small and informal businesses in employment, poverty alleviation and general economic growth is well recognized universally (Beyene, 2002). Current structures within the South African business environment meant to support small and informal businesses seem to be inadequate to support new business entrants, their long-term growth and sustainability. The difficulties that hamper the establishment, especially of small businesses, and sustainability thereof need to be clearly understood to drive economic growth 
within this sector and country as a whole. As it has previously been mentioned, the South African economy continues to grow at a lower rate compared to global and regional economies. As such, the country should rely on the small and informal business sector in job creation and general improvement of the economy.

In the endeavor to develop and sustain the small business sector, the South African government has established measures aimed at the creation a business environment that would support the existence and sustainability of small and informal businesses. The establishment of Small Enterprise Development Agency (SEDA), an agency of the Department of Small Business Development, is an attempt by South African government to assist small businesses in achieving their goals. The SEDA was established in 2004 with an aim to assist in the development, support and promotion of small enterprises throughout the country. The agency's 2015/2016 performance report indicates that the agency supported the establishment of 497 new Small, Medium and Micro-sized Enterprises during the mentioned period and in the process 2331 new jobs were created. Though many efforts have been directed by government towards helping the growth of small businesses in this country, the financing of establishment, operations and growth by small businesses remain an incredibly frustrating process, especially for first-time business owners. While the financial needs of large businesses are well served by equity markets and merchant banks, small businesses in South Africa continue to struggle to secure finance from financial institutions.

\section{LITERATURE REVIEW}

It is well recognized worldwide that small business sector plays an important role in any economic environment (Bhargava, 2004). Despite the importance of the small business sector, businesses operating in this sector continue to suffer as a result of the impediments relating to obtaining bank financing that is critical to their growth. Naude and Havenga (2004) found that excessive red tape and administrative burden was an impediment that small businesses struggled with in accessing finances from banks. A common theoretical argument that has been cited by many researchers is that of information asymmetry. Information asymmetry occurs where parties to an economic transaction possess greater or lesser material information to influence each other to the transaction. Information asymmetry thus leads to credit rationing on the part of banks (Berger \& Udel, 1998). Banks require information using which to evaluate the risk of a small business that is applying for finance, and to assess the prospects of the small business within the market segment and environment within which it operates. From bank's perspective, this information plays a critical role in the assessment of credit extension application to minimize potential risks.

Small businesses are owner-managed with little information that is published for a prospective investor to advance funding to the business. Banks often face difficulties in obtaining and collaborating information about small business owner-manager and the nature of business, thus, preventing them from better evaluating their loan proposals (Binks et al., 1992). Such information may relate to owner and management of the business, accounting records, financial statements and business plans. Compliance to certain accounting prescripts for the preparation of audited financial statements is a challenge for a small business entity. As such, smaller business entities do not keep proper accounting records and audited financial statements as there is no legal requirement to do so. Banks require audited financial statements to conduct a credit assessment of a business entity and in most cases requirement is not met by a smaller sized entity. The none availability of this information may prove to be detrimental to a small business as the bank may need this information for the purposes of credit extension. As a result, it becomes increasingly difficult for the bank to correctly assess the creditworthiness and business viability of a small business enterprise.

A factor that has been cited as influencing loan decisions by banks is the owner-manager conflict of interest embedded in small businesses. Most small and medium-sized business entities are privately owned. As such, the owner acts as the manager of the business. This is a factor that influences the sourcing of bank finance by the business as it has implication on the human capital of the business. 
Human capital refers to the skill, talent, and creative ideas or productivity that owner or employees bring to a business entity. Since human capital is difficult to measure, owner's education and experience is often used as yardstick to assess the application of loan by owner-manager of a small business. Coleman (2000) found that owner-manager's education are positively related to access to bank loan. Owner-managers who have acquired higher education levels are more likely to prepare financial statements, viable business plans and maintain a better relationship with banks compared to less educated entrepreneurs (Coleman, 2000). Further, educated owner-managers have better managerial skills which contribute to better business performance.

Agyapong et al. (2011) found entrepreneurial experience to be a valuable determinant used by banks to assess loan applications. Entrepreneurial experience is a yardstick that is used by banks to assess if credit can be extended to an owner-managed type of business. Experienced owner-managers have a track record and their business acumen can easily be traced from a quantifiable information. Well experienced owner-managers are deemed by banks to possess more financial skills and knowledge which can be used to support business management and development.

The entity's age and size is another consideration that banks look at when evaluating credit requests. Newer business entities are more likely to require more credit extension from banks to fund its establishment. Because of a limited credit history, newer businesses may find it difficult to access credit from banks owing to limited track record that may assist the bank in predicting the future probability of loan repayment. This has been amplified by Pandula (2011) who found that being in business for a longer period implies that the business has a verifiable track record and reputation. In addition, its competitive strengths can easily be ascertained. This was proved by Klapper et al. (2010) who found that businesses with less than 5 years in operation are less likely to rely on debt financing from lenders.

Beck (2007), Haron et al. (2013) amongst others have cited the lack of collateral as another obstacle facing the small businesses in sourcing bank finance. A collateral is a fixed or financial asset that a borrower offers as security to the lender to secure a loan. The availability of a collateral is one of the things that are considered by banks to accept or reject loan requests. A collateral is used to recover the capital amount borrowed and interest accrued in the event the borrower defaults on the obligations associated with the loan. In some instance, a business may not be able to provide sufficient collateral because of the age or has not been fully established with less asset base. This poses a limiting factor to a small business in terms of funding operations and growth.

\section{OBJECTIVE OF THE STUDY}

There is need for small businesses in South Africa to succeed given the role they play in the mainstream economy. As it has previously been mentioned, financing has been cited as one of the challenges faced by the small businesses. These challenges are a cause for concern and a serious threat to the establishment and sustainability of small businesses given the sector's role in the economy. With a recorded unemployment rate of $27.1 \%$ in the third quarter of 2016, the failure of a small business sector in South Africa is troubling.

With reference to the financing challenges faced by small business in this country, the objective of this paper was to identify significant factors that are a barrier in accessing finance by small businesses in South Africa. Although the reference of this study is to small businesses in South Africa, the researcher has deemed it necessary to limit the scope of the study to small businesses operating in Ekurhuleni Metropolitan area.

\section{HYPOTHESES}

The study will confirm or reject the following hypotheses:

- There is a relationship between the bank loan decision and the age of business.

There is a relationship between the bank loan decision and a business plan availability. 
- There is a relationship between the bank loan decision and the educational level of a business owner.

- There is a relationship between the bank loan decision and the business experience of the owner.

- There is a relationship between the bank loan decision and the availability of a collateral.

- There is a relationship between the bank loan decision and the continued existence of business.

\section{RESEARCH METHODOLOGY}

The data for this study was collected in 2016 by means of a survey. Questionnaires were handed out to small business owners who had applied for a bank loan, to finance their business operations, in the last 12 months. The population was limited to small businesses operating in Ekurhuleni Metropolitan area, in the province of Gauteng, South Africa. The interest in conducting a study in this area was motivated by high record of unemployment rate $34.6 \%$ in the second quarter of 2016 (Stats S A, 2016). The target population was restricted to owner-managers of small businesses in Ekurhuleni. The database of small enterprises of different forms of businesses was obtained from the Ekurhuleni business directory.

A simple random sampling process was applied to select respondents for the study. This method was deemed appropriate because of its uncomplicatedness and avoiding bias of selection. A sample size of 183 out of a total population of 350 small businesses in Ekurhuleni area was determined considering $95 \%$ confidence level and the margin of error of $5 \%$. An attempt to conduct a survey on
183 small business was made and only 144 small businesses met the selection criteria as they had applied for loan in the last 12 months. This indicated a response rate of $78.69 \%$ of businesses targeted for this study.

Respondents were asked if the loan proceeds were meant to be used to finance business operations and whether the loan was granted or declined. Further questions related to the business age; availability of business plans; educational background experience in business of the business owner or loan applicant. Respondents were also asked on whether the applicant provided a collateral in pursuit of a loan advance and whether the rejection of loan was a constraint in pursuit of business operations.

\section{RESULTS}

Based on the sample selected for this study, Tables 1-6 summarize the results of loan applications lodged by small businesses owners during the period under study. The results are presented according to factors considered to be the barriers in accessing bank finance by small businesses. A total of 144 small businesses applied for a bank loan of which $86(59.7 \%)$ were declined and 58 (40.3\%) were granted loans.

Table 1 details responses within the loan decision and business age factor. Younger small businesses (0-3 years) are the most that are declined loans. Within the loan decision, $43 \%$ of the declines relates to businesses that are younger than three (3) years. As the number of years increases a business is in existence, the likelihood of it being declined loan decreases. It is interesting to note that of the business that were granted loans, younger businesses are a majority (41.4\%), within the loan decision.

Table 1. Business age

\begin{tabular}{|c|c|c|c|c|c|}
\hline \multirow{2}{*}{\multicolumn{2}{|c|}{ Loan decision }} & \multicolumn{4}{|c|}{ Business age } \\
\hline & & $0-3$ & 4-6 & $7-10$ & Total \\
\hline \multirow{2}{*}{ Declined } & Count & 37 & 29 & 20 & 86 \\
\hline & \% within LoanDec & $43.0 \%$ & $33.7 \%$ & $23.3 \%$ & $100.0 \%$ \\
\hline \multirow{2}{*}{ Granted } & Count & 24 & 20 & 14 & 58 \\
\hline & $\%$ within LoanDec & $41.4 \%$ & $34.5 \%$ & $24.1 \%$ & $100.0 \%$ \\
\hline
\end{tabular}


Table 2. Business plan

\begin{tabular}{|c|c|c|c|c|}
\hline \multirow{2}{*}{\multicolumn{2}{|c|}{ Loan decision }} & \multicolumn{3}{|c|}{ Business plan provided } \\
\hline & & No & Yes & Total \\
\hline \multirow{2}{*}{ Declined } & Count & 61 & 25 & 86 \\
\hline & $\%$ within LoanDec & $70.9 \%$ & $29.1 \%$ & $100.0 \%$ \\
\hline \multirow{2}{*}{ Granted } & Count & 23 & 35 & 58 \\
\hline & $\%$ within LoanDec & $39.7 \%$ & $60.3 \%$ & $100.0 \%$ \\
\hline
\end{tabular}

The impact of a business plan on loan decision by banks is presented in Table 2. A business plan outlines the viability of a business venture and sets out a detailed explanation of what the business is all about, its financial position and projections. Of the loan applications that were declined, $70.9 \%$ had not provided business plans and $29.1 \%$ had provided business plans. The majority of businesses that received loans are those that provided business plans (60.3\%) in support of their application. Overall, loan decisions were more favorable to businesses that provided plans.

Table 3 reports on the business owner educational level and the outcome of the loan. Loan decisions appeared to be most unfavorable to business owners with lower or up to high school educational background with $44.2 \%$ that were declined and $10.3 \%$ granted loans. The results depict a very interesting picture on graduates (business owners with a single or first academic qualification) and post graduates. Most of the loan grants (72.4\%) were allotted to business owners with a single academic qualification, thus tilting post graduate business owners.

As depicted in Table 4, loan decisions seemed to favor seasoned business owners as opposed to less experienced business owners. Of the total of loans declined, $47.7 \%$ represented less experienced business owners. As the business experience increases, the lesser are the declines. Loan grants increases with the number of years the business owner is in business with the seasoned business owners receiving $70.7 \%$ of loan grants.

Table 3. Educational level

\begin{tabular}{|c|c|c|c|c|c|}
\hline \multirow{2}{*}{\multicolumn{2}{|c|}{ Loan decision }} & \multicolumn{4}{|c|}{ Education level } \\
\hline & & Matric & Graduate & Post Grad & Total \\
\hline \multirow{2}{*}{ Declined } & Count & 38 & 14 & 34 & 86 \\
\hline & \% within LoanDec & $44.2 \%$ & $16.3 \%$ & $39.5 \%$ & $100.0 \%$ \\
\hline \multirow{2}{*}{ Granted } & Count & 6 & 42 & 10 & 58 \\
\hline & \% within LoanDec & $10.3 \%$ & $72.4 \%$ & $17.2 \%$ & $100.0 \%$ \\
\hline
\end{tabular}

Table 4. Business owner experience

\begin{tabular}{|c|c|c|c|c|c|}
\hline \multirow{2}{*}{\multicolumn{2}{|c|}{ Loan decision }} & \multicolumn{4}{|c|}{ Business experience (in years) } \\
\hline & & $0-3$ & 4-6 & 7-10 & Total \\
\hline \multirow{2}{*}{ Declined } & Count & 41 & 31 & 14 & 86 \\
\hline & \% within LoanDec & $47.7 \%$ & $36.0 \%$ & $16.3 \%$ & $100.0 \%$ \\
\hline \multirow{2}{*}{ Granted } & Count & 6 & 11 & 41 & 58 \\
\hline & $\%$ within LoanDec & $10.3 \%$ & $19.0 \%$ & $70.7 \%$ & $100.0 \%$ \\
\hline
\end{tabular}

Table 5. Collateral provided

\begin{tabular}{|c|c|c|c|c|}
\hline \multirow{2}{*}{\multicolumn{2}{|c|}{ Loan decision }} & \multicolumn{3}{|c|}{ Collateral } \\
\hline & & No & Yes & Total \\
\hline \multirow{2}{*}{ Declined } & Count & 68 & 18 & 86 \\
\hline & \% within LoanDec & $79.1 \%$ & $20.9 \%$ & $100.0 \%$ \\
\hline \multirow{2}{*}{ Granted } & Count & 16 & 42 & 58 \\
\hline & \% within LoanDec & $27.6 \%$ & $72.4 \%$ & $100.0 \%$ \\
\hline
\end{tabular}


Table 6. Importance of a loan

\begin{tabular}{|c|c|c|c|c|}
\hline \multirow{2}{*}{\multicolumn{2}{|c|}{ Loan decision }} & \multicolumn{3}{|c|}{ Constraint } \\
\hline & & No & Yes & Total \\
\hline \multirow{2}{*}{ Declined } & Count & 11 & 75 & 86 \\
\hline & $\%$ within LoanDec & $12.8 \%$ & $87.2 \%$ & $100.0 \%$ \\
\hline \multirow{2}{*}{ Granted } & Count & 17 & 41 & 58 \\
\hline & $\%$ within LoanDec & $29.3 \%$ & $70.7 \%$ & $100.0 \%$ \\
\hline
\end{tabular}

The results shown in Table 5 report on the availability of a collateral on loan decisions. Much of small businesses did not provide collateral in support of their loan applications. Across the declined loan decision, $79.1 \%$ of businesses that applied for loan did not provide collateral in support of their loan application. The rest of the group (20.9\%) related to businesses that had provided collateral but still received an unfavorable decision on their loan application. Of the businesses that provided collateral, $72.4 \%$ received loan grants and $20.9 \%$ were declined.

Table 6 indicates the impact of loan decision on business operations and growth. A large number of small businesses surveyed seemed to rely on loans to pursue their business objectives. The results indicate that $87.2 \%$ of businesses that required loans desperately were declined and $12.8 \%$ of businesses were not constrained by the rejection of their loan applications.

\section{DISCUSSION OF RESULTS}

Pearson chi-square analysis was conducted to establish the degree of relationship between the factors identified for the purposes of this study and loan decisions. The factors considered are: age of business; availability of business plans; educational background of a business owner; business experience of a business owner; and availability of col- lateral. Further, this study also evaluated the relationship between the loan decision and the constraint posed to business operations and growth.

The test of a relationship between the loan decision and age of a business revealed a statistically insignificant relationship (chi-square $=0.039$ and significance $=0.980$ ) between the loan decision and business age. The hypothesis is therefore rejected. This means that the age of a small business in Ekurhuleni Metropolitan area has no bearing on whether the loan will be granted by bank or not. The result indicates that younger and established businesses have an equal chance of accessing bank finance. This finding is inconsistent with that of Beck et al. (2006) where it was found that older businesses, compared with younger ones, will find it easier to access finance. The result of this study also contradicts the findings by Abor (2008) on a study of businesses in Ghana, a developing country.

The provision of a business plan seems to have an influence on bank loan decisions. Table 7 reveals a significant relationship (chi-square $=13.940$ and significance $=0.000$ ) between the loan decision and the provision of a business plan. The hypothesis is therefore confirmed. This study indicates that loan decisions favor provision of a business plan. The result indicates that bankers prefer to advance funds to businesses that have clearly set out business strategies. The re-

Table 7. Chi-square tests

\begin{tabular}{l|c|c}
\hline & $\begin{array}{c}\text { Factor } \\
\text { relationship with loan decision }\end{array}$ & $\begin{array}{c}\text { Pearson } \\
\text { chi-square value }\end{array}$ \\
\hline Business age & Significance & 0.039 \\
\hline Business plan & 13.940 & 0.980 \\
\hline Business owner's educational level & 46.684 & 0.000 \\
\hline Business owner's experience & 45.103 & 0.000 \\
\hline Collateral & 37.774 & 0.000 \\
\hline Constraint & 6.035 & 0.000 \\
\hline N of valid cases 144 & & 014 \\
\hline
\end{tabular}


sult of this study is consistent with the findings by Abdesamed and Wahab (2012) who found that business plans play an important role in the bank loans assessment.

Business owner's educational level influences loan decision by banks. This study has established the existence of a statistically significant relationship (chi-square $=46.684$ and significance $=0.000$ ) between the loan decision and the level of education of the owner or applicant. The stated hypothesis is therefore confirmed. The result of this study confirms the finding by Irwin and Scott (2006) where it was found that education plays an important role in bank's lending decision, because entrepreneurs with better education have more chances to access funding from banks. This is because more educated business owners have better business acumen, as a result, they are capable of preparing convincing business plans and have better managerial abilities which can lead to a better business performance.

The result of this study indicates a high level of significance (chi-square $=45.103$ and significance $=$ 0.000 ) between loan decision and business owner's experience. The result confirmed the stated hypothesis and that business owners with less than three-year experience are more likely to be denied loans. This is consistent with the study conducted by Abdesamed and Wahab (2012) on 76 SMEs in Tripoli where it was found that there is a positive correlation between owner-managers' years of experience and their ability to borrow loans from banks. Experienced owner-managers usually have a broader base of business expertise and their business projections can be trusted based on the track record.

A significant relationship (chi-square $=37.774$ and significance $=0.000$ ) exists between the availability of a collateral and loan decisions. The hypothesis of this study is confirmed. This indicates that banks require some form of security to be provided in support of a loan application. This is a serious limiting factor because many small business owners cannot provide any form of assets that can be accepted by banks as a collateral.

As to whether the availability of loan was a constraint on business operations and growth, this study found a statistically significant relationship (chi-square $=6.035$ and significance $=0.014)$ between the availability of loan and the constraint it posed to business operations and growth. The hypothesis is confirmed. As it can be expected, businesses require funding to finance their operations and any lack thereof can be detrimental to the cash flow and capital investment of a small business.

\section{CONCLUSION}

The objective of this paper was to identify significant factors that are an impediment in accessing finance by small businesses in South Africa. The study was conducted in Ekurhuleni Metropolitan area, province of Gauteng, South Africa. The focus of this research was on businesses that have applied only for bank loans within a period of twelve months preceding the study. This research sought to validate if the relationship exists between the bank loan decisions and the factors such as business age, availability of business plan, educational background of business owner, business owner's experience and availability of collateral. The study also assessed whether the availability of finance from bank was a constraint on the continued existence of a small business.

The findings of the study revealed the existence of an insignificant relationship between the loan decision and the business age. This was inconsistent with the findings of other studies that have previously found that business age of small businesses, matters when it comes to the loan decision. The study found a significant relationship between the loan decision and factors such as: the availability of a business plan, educational background of business owner, business owner's experience and availability of collateral. The study further assessed if the availability of loan to small businesses was constraint in their pursuit of business endeavors. It was found that a significant relationship exists between the availability of loan and continued existence of small businesses in Ekurhuleni. 
Given the impact of the small business sector on the Ekurhuleni economy and South Africa in general, the research findings should guide policy makers in crafting financing models for small businesses. This will be in considering the factors that have been identified in this study as having an influence on the loan decisions. The small business sector plays an important role in the development of a business sector and obstacles, such as access to finance, are an impediment towards economic growth.

The limitation that has been observed in pursuit of this research relates to the number of factors that were included in this study. The number of factors considered to having an impact on the loan decisions was restricted to six (6) factors. Future research work may attempt to include other factors which are likely to contribute to loan decisions by banks, for example, creditworthiness and indebtedness of the small business owners who were applicants in this case.

\section{REFERENCES}

1. Abdesamed, K. H. \& Wahab, K. A. (2012). Do experience, education and business plan influence SMEs start up bank loan? The case of Libya. Australian Journal of Basic and Applied Sciences, 6(12), 234-239.

2. Abor, J. (2008). Determinants of the capital structure of Ghanaian firms. African Economic Research Consortium, Nairobi. AERC Research Paper 176. Retrieved from http:// dspace.africaportal.org/jspui/ bitstream/123456789/32100/1/ RP176.pdf?1

3. Agyapong, D., Agyapong, G. K. Q., \& Darfor, K. N. (2011). Criteria for Assessing Small and Medium Enterprises Borrowers in Ghana. International Business Research, 4(4), 132-138.

4. Beck, T. (2007). Financing Contraints of SMEs in Developing Countries: Evidence, determinants and solutions. Journal of International Money and Finance, 27(1), 1-7.

5. Beck, T., \& Demirguc-Kunt, A. (2006). Small and medium-size enterprises: Access to finance as a growth constraint. Journal of Banking Finance, 30, 2931-2943.

6. Berger, A. N., \& Udell, G. F. (2002). Small Business Credit Availability and Relationship Lending: The Importance of Bank Organisational Structure. Economic Journal, 112, F32-F53. Retrieved from http://onlinelibrary.wiley.com/ doi/10.1111/1468-0297.00682/full
7. Berger, T. N., \& Udell, G. F. (1998). The Economics of Small Business Finance: The Roles of Private Equity and Debt Markets in the Financial Growth Cycle. Journal of Banking and Finance, 22, 613673. Retrieved from http://www. sciencedirect.com/science/article/ pii/S0378426698000387

8. Berry, A. E. (2002). The Economics of SMMEs in South Africa. Pretoria: Trade and Industry Policy Strategies. Retrieved from http://www.smmeresearch.co.za/ SMME\%20Research\%20General/ Reports/Economics\%20of\%20 SMMEs\%20in\%20SA.pdf

9. Beyene, A. (2002). Enhancing the Competitiveness and Productivity of Small and Medium Scale Enterprises (SMEs) in Africa: An Analysis of Differential Roles of National Governments Through Improved Support Services. Africa Development, XXVII(3), 130-156. Retrieved from http://unpan1un. org/intradoc/groups/public/documents/IDEP/UNPAN01339.pdf

10. Bhargava S. 2004. Developing competitive advantage through SMEs to face WTO regime. Journal of the Chartered Institute of Chartered Accountants, August, 176-187.

11. Binks, M. R., \& Ennew, C. T. (1996). Information Asymmetries and the Provision of Finance to Small Firms. Small Business Economics, 8, 17-25. Retrieved from http://journals.sagepub.com/doi/ abs/10.1177/026624269201100103
12. Bosa, G. R. (1969). The Financing of Small-scale Enterprises in Uganda. Occasional Paper, 3. Nairobi: Oxford University Press/ Makerere Institute of Social Research. Retrieved from https:// scholar.google.co.za/scholar?q=JT he+Financing+of+Small-scale+En terprises+in+Uganda\&btnG $=$ \&hl $=$ en $\& a s \_s d t=0 \% 2 C 5 \& a s \_v i s=1$

13. Carter, S., \& Shaw, E. (2006). Women's business ownership: recent research and policy developments. Report to the Small Business Service. Retrieved from: http://tna.europarchive. org/20081112122150/http://www. berr.gov.uk/files/file38330

14. Cassar, G. (2004). The Financing of business start-ups. Journal of Business Venturing, 19(2), 261-283.

15. Chimucheka, T. (2015). The Contribution of Entrepreneurship Education in Improving Entrepreneurial Skills and Knowledge of SMME Owners and Managers. Journal of Economics, 6(2), 149-155.

16. Coleman, S. (2000). Access to Capital and Terms of Credit: A Comparison of Men- and WomenOwned Small Businesses. Journal of Small Business Management, 11(1) 35-46.

17. Department of Trade and Industry (The DTI) (2008). An Annual Review of Small Business in South Africa, (2005-2007). The DTI, Republic of South Africa.

18. Haron, H., Said, S. B., Jayaraman, K. \& Ismail, I. (2013). Factors 
Influencing Small Medium Enterprises (SMES) in Obtaining Loan. International Journal of Business and Social Science, 4(15), 182-195.

19. Herrington, M., \& Kew, P. (2016). Is South Africa heading for an economic meltdown? Global Entrepreneurship Monitor (GEM). South African Report 2015/16. Retrieved from http:// www.gemconsortium.org/report

20. Irwin, D., \& Scott, J. M. (2006). Barriers faced by SMEs in raising bank finance. Institute of small business and entrepreneurship conference (ISBE). Cardiff: November 2006.

21. Keasey, K., \& Watson, R. (1994). The Bank Financing of Small Firms in UK: Issues and Evidence. Small Business Economics, 6(5), 349-362. Retrieved from https:// link.springer.com/article/10.1007 $\% 2 F B F 01065138$ ?LI=true

22. Klapper, Leora, F., Parker, Simon, C. (2010). Gender and the business environment for new firm creation. The World Bank research observer, 26(2), 237-257. Retrieved from https:// academic.oup.com/wbro/articleabstract/26/2/237/1640282
23. Levy, B. (1993). Obstacles to Developing Indigenous Small and Medium Enterprises: An Empirical Assessment. The World Bank Economic Review, 7(1), 65-83. Retrieved from https:// academic.oup.com/wber/articleabstract/7/1/65/1688722

24. Mijid, N. (2009). Gender, Race, and Credit Rationing of Small Businesses: Empirical Evidence from the 2003 Survey of Small Business Finances. Ph.D. thesis, Colorado State University. Retrieved from https://search. proquest.com/openview/bcd7c9 18e89dc1c094e7c8548aeb009f/1 ?pq-origsite $=$ gscholar \&cbl $=1875$ 0\&diss $=\mathrm{y}$

25. Naude, W. A., \& Havenga, J. J. D. (2004). An Overview of African Entrepreneurship and Small Business Research. Journal of Small Business Entrepreneurship, 18(1), 101-120.

26. Nieman, G., \& Neuwenhuizen, C. (2009). Entrepreneurship: A South African Perspective. Pretoria: Van Schaik.

27. Pandula, G. (2011). An Empirical Investigation of Small and Medium Enterprises' Access to Bank Finance: The Case of an Emerging Economy. ASBBS Annual Conference, Proceedings of ASBBS, Las Vegas, 18, 255-273.

28. Statistics South Africa (2016). Statistical release P0211. Pretoria: Republic of South Africa. Retrieved from http://www.statssa.gov.za/publications/P0211/ P02113rdQuarter2016.pdf

29. Statistics South Africa (2016) Statistical release P0441. Pretoria: Republic of South Africa.

Retrieved from http://www.statssa.gov.za/publications/P0441/ P04413rdQuarter2016.pdf

30. The Banking Association South Africa. (2016). SME Enterprise. Retrieved from http://www.banking.org.za/what-we-do/sme/smeenterprise

31. Wilson, F., Carter, S., Tagg, S., Shaw, E., \& Lam, W. (2007). Bank loan officers' perceptions of business owners: The role of gender. British Journal of Management, 18(2), 154-171. Retrieved from http://onlinelibrary. wiley.com/doi/10.1111/j.14678551.2006.00508.x/full 